University for Business and Technology in Kosovo

UBT Knowledge Center

UBT International Conference

2012 UBT International Conference

Nov 2nd, 9:00 AM - Nov 3rd, 5:00 PM

\title{
Analysing toruism consultancy market in Albania. Problems and conditions
}

Fioralba Vela

University of Vlora

Ermelinda Kordha

University of Vlora

Follow this and additional works at: https://knowledgecenter.ubt-uni.net/conference

Part of the Business Commons

\section{Recommended Citation}

Vela, Fioralba and Kordha, Ermelinda, "Analysing toruism consultancy market in Albania. Problems and conditions" (2012). UBT International Conference. 47.

https://knowledgecenter.ubt-uni.net/conference/2012/all-events/47

This Event is brought to you for free and open access by the Publication and Journals at UBT Knowledge Center. It has been accepted for inclusion in UBT International Conference by an authorized administrator of UBT Knowledge Center. For more information, please contact knowledge.center@ubt-uni.net. 


\title{
Marketing of a destination. Critical factors of a destination marketing success from of Stakeholders' and customer' perspective. The case of Macedonia and Albania
}

\author{
Jovan Stojanoski, $\mathrm{Ph} \mathrm{D}^{1}$ \\ ${ }^{I}$ Faculty of Tourism and Hospitality, Ohrid, Macedonia \\ Liljana Elmazi, $\mathrm{PhD}^{2}$ \\ ${ }^{2}$ Faculty of Economics, University of Tirana Albania
}

\begin{abstract}
This study investigates the internal and external environmental factors that affect destination marketing in Macedonia and Albania and the use of the destination marketing concept by tourism companies in Macedonia and Albania. Furthermore, special emphasis is placed on investigating and identifying the existing relationship between the internal and external factors in destination marketing by pinpointing the factors being used by tourism companies and those factors that contribute to the attraction of tourists to Macedonia and Albania. The empirical research to support the study uses survey methods to develop and test the critical factors of a destination marketing success model that can be used to market and promote Macedonia and Albania, regionally and globally, as a preferred tourism destination area.

We are guided by a deductive method regarding the groups of tourist destination attitudes and practices of marketing with consistency of questionnaire responses in comparison with available literature on the subject. The results were quantitatively analysed by using SPSS.

This study contributes to the field of tourism through testing a destination marketing success model that can be applied to global destinations. This paper is designed to address the marketing of the tourist destination in an endeavour to suggest a marketing framework and to formulate appropriate tourism marketing strategies for Macedonia and Albania.
\end{abstract}

\section{Problem of the Study}

The key question of this paper is how to market and promote Macedonia's and Albania's tourism, regionally and globally. It is worth mentioning that tourism is a growing industry which plays a large part in contributing to the economic well-being of Macedonia and Albania.

\section{Objectives of the Study}

1. To investigate the internal and external environmental factors that affect destination marketing in Macedonia and Albania.

2. To investigate the use of the destination marketing concept by tourism companies in Macedonia and Albania.

3. To investigate the relationship between the internal and external factors in destination marketing by a) Identifying the factors being used by tourism companies and b) Identifying the factors that contribute to the attraction of tourists to Macedonia and Albania.

\section{MARKETING OF A DESTINATION}

A destination planning model has been developed by Crouch and Ritchie (1999), which they call a destination competitiveness model. This model has comparative and competitive advantages, where comparative advantage represents the destination's factor endowments, while competitive advantage relates to a destination's ability to use the resources effectively over the long -term (Crouch and Ritchie, 1999).

The leading destinations offer excellent service and facilities, accommodation and attractions with unique culture and heritage. Therefore, the ten major destinations attract seventy per cent of the worldwide tourism market (Piggott, 2001; Lozano et al, 2005).

Destination development has some important factors to attract outside interests to its destinations. These factors depend upon the location and complexity of the destination. While branding is part of destination development it is a powerful weapon in the marketing which is confronted by increasing rivalry, product parity and substitutability (Dimanche, 2003). Therefore, the study of destination marketing development indicates that organizations need to identify specific destinations that can be improved by their marketing efforts (Alan, 2003).

\section{Definition of Destination}

The word 'destination' is one of the most used in the fields of tourism, marketing, planning and development and general research. One can find it in tourist guides, homepages, brochures and all types of textbooks and readers in tourism. Destinat ion 
also contains some tourism aspects that can be found in various dimensions and on various regional levels. For example, static destinations exist in connection with one's stay at a certain location, while dynamic destinations movement is the motive for a vacation and is connected to networks and other relations in the tourism industry (Framke, 2001).

There are definitions of destination by some authors that are based upon the following approaches (Geogulas, 1970; Cohen, 1974; Butkart and Medlik, 1974; MacCannel, 1976; Murphy, 1985; Mill and Morrison, 1992; Cooper et al, 1993; Framke, 1999, 2000, 2001; Baerenholdt and Framke, 2000; Baerenholdt, 2001; Meethan, 2001; Jensen, 2001; Lubbe, 2003; Hazbun, 2004; Taji, 2005).

\section{Aspects of Destination Marketing}

The importance of the aspects is to apply a good relationship between the marketing of services and the marketing of destinations. These aspects have been applied in this research and summarized.

\section{1 - Evolution of the Destination Marketing}

According to Wintjen (2004), the evaluation of modern destination marketing organizations is described as a private sector of tourism organization based on the tourism source markets. It explains how culture cooperation between competing, mainly small and medium tourism actors in long haul destinations, is cultivated overtime rather than installed by some technique. It provides information to consumers, travel agencies, wholesalers and generalists, sending out information packaging (Wintjen, 2004).

2- Keys of Destination Marketing Database

Destination database development is considered as a key to effective marketing that focuses directly on the question of who will control the information flow and market access within the tourism industry. The emphasis increasingly relates directly to individual customers by developing the product they need, delivering that product with skilled staff and having the systems to tie it all together. This has led to new marketing requirements for reaching individual customers and meeting their needs.

These changes are made possible by the technology that facilitates direct supplier /customer contact delivery (Archdale, 1991). Destination marketing effectiveness will be measured by visitors arrival or room nights revenues, not advertising impressions counted. Typical marketing involves an array of organizations jointly offering the product, which is the travel experience.

\section{Critical Strategic Factors of Destination Marketing Success}

The key aim of this thesis was to design a model that will enable the tactical identification and integration of critical factors of tourist destination marketing success (Rockart, 1979; Leidecker \& Bruno, 1984; Clements, (1989); Manning, 1998; Maquablih and Darabi, 2000; Lynch, 2000, 2003, Leu, 2004; Hendrie, 2004; Morrison et al, 2005). The objective of this section is to analyse the modern literature on critical factors of destination marketing: firstly, to provide a perspective on the nature a nd extent of critical factors of destination marketing success; secondly, to identify possible sources of critical factors of destination marketing success; finally, to determine the importance of success factor and how it can be measured.

\section{The Nature and Extent of Critical Factors of Destination Marketing Success}

Fishman (1998) points out that well-defined aims are critical to the success of any organization or destination, but this study will identify the critical factors of destination marketing success needed to attain these aims. Daniel (1961) was the first person to mention the concept of critical factors (or factors that are critical to success).

Rockart (1979) defines critical factors of success as "Critical factors of success thus are, for any business, the limited nu mber of areas in which results, if they are satisfactory, will insure successful competitive performance for the organization, they are the critical key areas where 'things must go right' for the business to flourish. If results in these areas are not adequate, the organization's efforts for the period will be less than defined" (p.85). Therefore, the themes of both Daniel's and Rockart's approaches were the provision of better information to management for more effective control and planning. The important contribution of their work was the focus on critical areas, rather than a vague attack on all problems areas.

An important feature of this definition is the acknowledgement that the characteristics of the industry affect the critical factors for the success of firms in that industry. Also, critical factors of success for any industry were considered u nimportant to the need for control and planning within the company.

From the definitions and views provided, there appear to be some common characteristics that assist to explain the nature and extent of critical factors for success.

1- Critical factors of success are the sub-aims and/or success outcomes that are directly related and critical to the accomplishment of the vision, mission and long-term aims of the organization.

2- Critical factors of success can be internal and external areas, such as resources, skills, capabilities, attribute conditions, market, product features and gainful market segments.

3- Critical factors of success are limited areas of success that will assert the successful competitive performance of the organization.

4- Critical factors of success are result areas in which success can be measured.

These critical factors are normally resolute at two distinct levels: the industry level and the organization level (Rockart, 1979; Leidecker \& Bruno, 1984; Clements, (1989); Manning, 1998; Maquablih and Darabi, 2000; Lynch, 2000, 2003, Leu, 2004). 
Each industry, by its nature, has a set of critical factors of success determined by the industry itself. Each organization in the industry will pay attention to those factors and use them as standards for competitive performance.

\section{The Identification of Critical Factors of Destination Marketing Success}

The critical factors can be identified at different levels and sources. The goal of this is to analyse the sources of critical factors for success that evaluate the criticism on their identification. Authors (Rockart, 1979; Leidecker \& Bruno, 1984; Pearce \& Robenson, 1991; Shirvastava, 1994; Hax \& Majluf, 1996; Lynch, 2000, 2003) of the sources of critical factors for success differ; there appears to be agreement on three sources.

\section{1- Environmental Factors}

The major advantage of the environmental analysis is the width of the analysis as the scope goes beyond the industry/or compa ny interface. The external environment includes economic, social, technological, ecological, political and legal factors that originate beyond, usually irrespective of, any single firm's operating situation.

As the world economy and political factors change and ecological factors become more important, critical factors of succes s will also change for different industries and organizations (Pearce\& Robenson, 1991; Shirvastava, 1994; Wright et al, 1996). The environmental examine is based upon the identification of those critical factors for success to be the central determinants of attractiveness of a particular industry (Hax \& Majluf, 1996). Therefore, the success of a particular industry is affected by the current and future impact of external and internal factors where they impact on the tourism industry.

\section{2- Industry Factors}

Critical factors of destination marketing success can be represented by rivalry, geographic, location, markets and characteristics. Lynch (2003) defines industry success factors as "those skills and attributes of the organizations in the industry that are essential to deliver success to the marketplace" (p.102). Industry success factors are common to all the major organizations in the ind ustry and do not differentiate one organization from the others (Leidecker \& Bruno, 1984; Lynch, 2003). According to Lynch (2003), industry success factors will relate to the external and internal environment as well as to the resources and skills of the organization in the industry and he summaries the views mentioned earlier by indicating that industry success factors should be identified by the appraisal of three principal areas:

A- Customer. Who are the customers? Who are the potential customers? Are there any special market segments? What are the market segments of the future?

B- Rivalry. Who are the main challengers? What are the main factors in the market that influence rivalry? What is necessary to accomplish market superiority?

C- Organization or Corporation. What are the key resources compared with those of the challengers? What do they offer and deliver to the customers?

Crouch and Ritchie (1999) identify tourism success factors, or so called "situational qualifiers", that will decide the compe titive success of a tourism destination where the industry success factors are location, dependences, security and safety, and cost.

(1)- Location. This refers to the destination's ability to attract visitors.

(2)- Dependences. This refers to the competitive or balancing nature of destinations that could have an important effect on the competitiveness of the destination.

(3)- Security and Safety. This is globally considered a critical factor of destination marketing success for a tourism destination to be competitive. As such, if potential tourists are concerned about crime, drinking water, natural disasters, or the quality of medical services, other competitive strengths may account for very little in their minds.

(4)- Cost. This is the cost of living in a destination, particularly of tourist goods and services. It is also largely a destination success factor in its widest terms (i.e. transportation costs, the effect of exchange rates. Crouch and Ritchie (1999) indicate that, although the nationwide tourism industry can impact on this cost, the cost of a destination is largely driven by much wider s ocioeconomic and global forces.

Thompson and Strickland (2002) view industry success factors as the major determinants of financial and competitive success in a particular industry. They show that the identification of the success factors in an industry is a top strategic is sue as these factors normally serve as cornerstones for building organization's policy.

\section{3- Organizational Factors}

In this study, resources, skills, strengths, capabilities and competitive advantages represent destination competitive policy . Just as differences in industry position can say critical factors for success, differences in geographical location, resources, capabilities and cutthroat policies can lead to differences from one organization to another (Rockart, 1979; and Johnson \& Scholes, 2002). Therefore, organizations in the same industry would exhibit different critical factors for success as a result of differences in geographical location, resources, policies and other factors.

In determining critical factors of success at the organizational level, the analysis provides a number of steps. These steps of the various sources (including Rockart, 1979; Hardaker and Ward, 1987; Kaplan and Norton, 1996; Johnson \& Scholes, 2002) can be summarized in the following ways:

A- Gather the Team. The team should consist of the leadership of the organization or destination and everyone in the urgent management team. The team should be cross-functional to as sert the integration of all functions. 
B- Understand and Clarify the Vision, Mission and Strategic Position. The team should reach agreement on the organization's direction by agreeing on vision and strategic position. Fishman (1998) points out that each member must understand the organizations aims and how the critical factors for success can be appraised to accomplish them.

C- Generate Critical Factors of Success. Critical factors of success should have the following characteristics when they have been generated:

(1)- the accomplishment should be critical for success

(2)- each critical factors of success should be necessary and together they should be sufficient to attain the overall vision, mission and policies

(3)- they should contain planned as well as strategic factors.

D- Identify the Foundation Capabilities. Johnson \& Scholes (2002) defined capabilities as "those capabilities that critically under pin the organizations competitive advantage" (p.157). They argue that critical factors of success are founded by core capabilities. Therefore, these capabilities are essential in gaining competitive advantage in each of critical factors of success.

E- Balance, Integrate and Measure Critical Factors of Success. Critical factors of success should be balanced, integrated and measured for superior long-term financial and competitive performance:

(1)- Critical factors of success should be limited and balanced between all the important respective of the organization

(2)- Critical factors of success should be integrated with the processes that are critical for accomplishing breakthrough performance

(3)- Critical factors of success should be measured by critical integrators that will direct and manage the process for best success.

\section{Determination of Factor Importance}

The impact of any activity or condition and the income of the organization are usually the most significant criteria for iden tifying a critical factor of success and determining its importance. Leidecker \& Bruno (1984) suggest four points for the profit impact analysis that will help in determining factors importance.

1- Major Activity of Business

Critical factors of success are found in the major area of business. According to Kaplan and Norton (1996), these major areas can be divided into four perspectives: financial, customer, internal process and learning and growth.

\section{2- Large Amount of Money Involved}

A major factor will have a large amount of money associated with it. For instance, in a manufacturing company direct labour maybe a large cost component and, therefore, the productivity of the work force might be a critical factor of success.

3- Major Profit Impact

An impact analysis will appraise the understanding of overall results to changes to cretin activities where, under circumstances, a small change in price might have an immense bottom-line impact.

4-Major Changes in Performance

A major profit reversal in a segment of the operation is to follow up on changes of the companies' performance, such as dramatic drop in sales and a sizable increase in bargains, where a significant change can be linked to a major critical factor of succ ess. There are two ways of determining the importance of a critical factor of success.

A- Panels (Brainstorming). A management group or panel prioritises the critical factors of success according to their importance (Fit-enz, 1985).

B- Weighted Values. These are designed by deciding how the organization performs on each critical factor of success (using the one to five or one to ten rating scale) and multiplying the value by the assigned weight to obtain the weighted value (Hofer \& Schendel, 1978; and Thompson and Strickland, 2002). Weights are attached to the different critical factors of success that reflect their relative impact on overall profitability, market share and other measures of cutthroat position.

According to Goodstein et al, (1992), critical success indicators should be developed "to calibrate the progress toward achieving the organization's mission". These indicators are a mix of hard and soft indices of success, such as opinions of customers ab out service, employee morale and the attitudes of stakeholders inside and outside the firm.

The success factors and measures of the scorecard are derived from the organization's vision and overall policy, while the objectives and measures view organizational performance from four perspectives: financial, customer, internal business proces $\mathrm{s}$ and learning and growth. A control panel of key indicators of organizational success is designed to assist employees 'pilot' the organization by identifying critical factors of success, especially those that can be measured as physical variables (Lebas, 1994).

\section{Strategic Integration for Critical Factors of Success}

The strategic integration makes provision for identifying and integrating critical factors of destination marketing success by using the following perspectives.

1- Sustainable Growth

WTTC (2001) notes that "sustainable travel and tourism development relies upon policies which support harmonious relationships among travellers, local communities, the private sector and governments to balance natural, built and cultural environments with economic growth and stability". Therefore, social success indicators will measure sustainable growth that can include environmental sustainability, employment creation and supportive communities.

The sustainable growth perspective measures the sustainable growth that the tou rist destination generates for all the stakeholders. This measurement is arrived at through economic indicators and social indicators. According to Hassan (2000), it is also crit ical 
for destination development plans to be well-matched with environmental and social integrity for the tourism industry to maintain its economic viability. Gainful

enterprises are critical for the economic development in the industry.

2- Customer Perception

The last aim of the tourist perception is to add optimum value to the tou rist experience at the tourism destination area. The market segments in which the destination would like to compete and the differentiating factors in each section are inputs int o the tourist perception.

Kaplan and Norton (1996) divide customer value propositions into three parts: customer accomplishment, satisfaction and retention. The critical success area identified for tourist acquisition is destination image.

\section{Important Assumptions Fundamental the Model}

The following fundamental assumptions are important for the success of the model.

1- Worldwide Destination Competitiveness

A number of studies have introduced and applied the concept of competitiveness in the area of tourist destination marketing for planning (Bordas, 1994; Pearce, 1997; Crouch and Ritchie, 1999; Buhalis, 2000; Hassan, 2000; Michalic, 2000; Kozak, 2001, 2004). The major interest of the existing studies has been to investigate how destination competitiveness can be sustained as well as enhanced while maintaining a strategic market position among other destination challengers.

Studies have also investigated the key environmental factors, determinants, or policies that affect the enhancement of destin ation competitiveness. It has been discussed that, since tourist destinations marketing involve multi-faceted elements of natural/cultural resources and a multiplicity of businesses, a systematic framework or analytical model for destination plann ing and development is necessary (Hassan, 2000).

Yoon (2002) argues that one of the aims of tourism planning and development is to create more valuable tourism products and services for potential customers.

However, for current tourists where the destinations and their communities receive social and economic benefits, there is a n eed for a clear understanding of the ability of the tourist destination marketing to compete effectively in an increasingly saturated market (Evans et al, 1995; Crouch and Ritchie, 2000). Therefore, planning and promotion of tourist destination marketing shou ld be guided by a thorough analysis of the destination's competitive factors and developed policies (Hassan, 2000).

\section{Figure 1: Models of Critical Factors of Destination Marketing Success Worldwide Environment}

\section{Worldwide Destination Competitiveness}

1. Worldwide competitive appraisal

2. Worldwide resource and factor analys is

3. Worldwide market analysis

4. Worldwide critical factors

5. Worldwide challenger analysis

Nationwide Environment

Destination Deriction and Positioning

1. Stakeholder values

2. Shared vision

3. Strategic position

4. Strategic capabilities

5. Critical factors

Critical Factors of Destination Marketing Success (Tourist Satisfaction)

1. Product

2. Quality of service

3. Accessibility

4. Promotion

5. Price

6. People

7. Physical evidence

\section{Tourist Destination and Promotion}

The aim of this section is to advocate performance of the effectiveness of promotion in causing visit to a destination area. The key points are:

1- tourism destinations are responsible for allocating substantial promotional funds to attract visitors which given by destination marketing managers

2- while conversion studies are valuable for evaluating alternative messages and media vehicles, they are adequate substitutes to learn the effect of advertising on sales. 


\section{RESEARCH METHODOLOGY}

\section{Research Objectives}

The emergence of the tourism destination has been one of the major growth sectors in Macedonia and Albania for the last two decades. The objectives of tourist destination marketing in Macedonia and Albania as a case study are:

1. To investigate the external and internal environmental factors that affect destination marketing in Macedonia and Albania

2. To investigate the use of the destination marketing concept by tourism companies in Macedonia and Albania

3. To investigate the relationship between the internal and external factors in destination marketing: a) By identifying the factors being used by tourism companies b) By identifying the factors that contribute to the attraction of tourists to Macedonia and Albania.

\section{Quantitative Research}

Quantitative research involves the use of structured questions where the response options have been fixed and a large number of respondents are involved. The aim of quantitative research is to determine the relationship between one factor (a dependent or outcome variable) and another (an independent variable) in a population. Quantitative research designs are either descriptive (subjects usually measured once) or experimental (subjects measured before and after a treatment). A descriptive study establishes only as sociations between variables (Hopkins, 2000).

Quantitative research is about quantifying relationships between variables. Variables are features like weight, performance, time and treatment. Variables measure a sample of subjects, which can be tissues, cells, animals, or humans. The relationship between variables can be expressed by using effect statistics, such as correlations, relative frequencies, or differences between means that deal with these statistics and other aspects of analysis.

For an accurate estimate of the relationship between variables, a descriptive study usually needs a sample The estimate of the relationship is less likely to be influenced if they have a high participation rate in a sample selected randomly from a popu lation. The sample size involved in this study is 240 questionnaires which were sent out by postal and electronic mail to the representatives to accomplish the largest possible response. Thus, of the remaining 240 questionnaires, 180 us able questionna ires were completed and returned (30stakeholders and 150 customers).

The formulation of the hypotheses were defined and tested in the context of tourism. A survey was used as the empirical research process for the research design and collecting the data. This survey was carried out by means of a questionnaire which was distributed and the data collected was analysed to accomplish the research objectives. Therefore, the population in this study was two types: the worldwide tourists that visit Macedonia and Albania and the nationwide stakeholders of the Macedonian and Albanian tourism.

The following factors were listed by the respondents: the most effective reason for visiting Macedonia and Albania, all comfortable physical environment, Macedonia and Albania is a safe and secure country, Macedonian and Albanian people, understanding the needs and demands of tourists and accessibility of Macedonian and Albanian tourism as critical success factors that have the same mean score and rank.

However, these factors were considered by the respondents to have an impact on tourist satisfaction and increase the number of visitors to the tourism sites.

American tourists considered that Macedonia and Albania is a safe and secure country for tourists and Macedonian and Albanian people are friendly and hospitable are the most important factors in visiting Macedonia and Albania. Also, with the existing safety and security problems that Macedonia and Albania is experiencing, tourist respondents considered that the safety of tourists is a critical factor of success to manage and control in the future.

West European tourists considered that the most effective reasonfor visiting Macedonia and Albania is tourism sites as the most important factor to interact with tourists. Therefore, this factor is the most critical success factor in affecting their tourist satisfaction and enhancing the tourist destination marketing.

The tourist from Balcanian countries tourists and others considered that understanding the needs and demands of tourists is the most important factor for visiting the destination of Macedonia and Albania. However, understanding the needs and demands of tourists increases the number of visitors to the Macedonian and Albanian tourism sites.

\section{2-Stakeholders}

The study shows the response percentages and mean of the stakeholder factors destination marketing success. The most critical factor identified by the respondents is that tourist satisfaction is a prime objective in designing the working atmosphere of Macedonian and Albanian tourism. The mean score ranges between 4.8 and 4.

According to the stakeholders' view understanding the needs and demands of tourists have the same mean score and rank 4, while Macedonia and Albania is a safe and secure country for tourists and knowing Macedonian and Albanian tourism have the same mean score and rank 7. Three additional critical success factors listed by the respondents that added important value to the tourist satisfactions included culture, eco and adventure tourism experiences. 
Macedonia and Albania has the necessary experience in hospitality, safety and security for tourists, while managers of restaurants, accommodation and tourism attractions ranked infrastructure of Macedonian and Albanian tourismas 3 in the order of importance. Thus, the infrastructure of Macedonian and Albanian tourism affected the level of tourists' attractions. Sales managers listed Accessibility of Macedonian and Albanian tourism as more important of the Macedonian and Albanian tourism products than marketing managers. Thus, accessibility of Macedonia and Albanian tourism has an impact on increasing tourist satisfactions.

\section{3- Comparis on of Tourists and Stakeholders}

Our study shows the differences in factors of performance for both international tourists and national stakeholders in Macedonia and Albania. However, tourist respondents agreed that all the twelve factors were critical, while respondents for stakeholders considered that their ten factors of performance were critical.

Worldwide tourists and nationwide stakeholders considered the indicators of performance as critical success factors in enhancing the tourism destinations. They listed Macedonia and Albania's tourism products as important success factors in selling and promoting them regionally and globally.

The responses of tourist respondents considered that the sites of Macedonian and Albanian tourism are well known in the World Tourism Organization (WTO) as the most critical factor, while respondents for stakeholders considered that tourist satisfaction is a prime objective in designing the working atmosphere of Macedonian and Albanian tourism is the most critical factor.

Tourist respondents considered the three most critical success factors in order of importance.

1- The Sites of Macedonian and Albanian tourism are well known in the World Tourism Organization (WTO) for tourists with a value of $89.3 \%$ while, for stakeholders, it was ranked 6 by a value of $27.7 \%$.

2- Improved Macedonian and Albanian tourism image builds a good relationship with tourists, and known about Macedonian and Albanian tourism through several means are important factors for tourists by a value of $79.5 \%$, but, for stakeholders, they ranked 4 and 7 , by a value of $47.3 \%$ and $20.6 \%$, respectively.

3- Tourist satisfaction is a prime objective in designing the working atmosphere of Macedonian and Albania's tourism ranked number 4 for tourists with a value of $62.6 \%$ while, for stakeholders, it ranked 1 with a value of $82.1 \%$.

According to the tourists' view, respondents considered that knowing Macedonian and Albanian tourism products comes first in priority, followed by improvement of Macedonian and Albanian image and then tourist satisfactions. However, according to the stakeholders' view, the respondents considered that tourist satisfaction always comes first, followed by the Macedonian and Albanian friendship and infrastructure of its tourism, then improvement of Macedonia and Albanian image. Therefore, tourists dealt with tourists' needs and wants while stakeholders dealt practically with customers' needs and wants.

Respondents considered that the following factors for stakeholders are the most critical success factors and ranked them in o rder of importance.

Managers of restaurants and accommodation considered that infrastructure of Macedonian and Albanian tourism ranked as the most critical success indicator. Thus, they totally agreed with managers of tourismattractions that infrastructure of Macedonian and Albanian tourism affected the level of tourists' attractions. Sales managers identified that accessibility of Macedonian and Albanian tourism is the most important factor, but marketing managers considered that the Macedonia and Albania tourism products was most important. Therefore, they disagreed with managers of marketing that accessibility of Macedonia and Albania tourism has an impact on increasing tourist satisfactions. Nevertheless, all national stakeholder respondents identified their indicators of performance as critical factors of success in promoting Macedonian and Albania's tourism regionally and internationally. As a result, these stakeholders' indicators are crucial success factors in measuring customer satisfaction.

\section{Service Quality and Quality of Experience}

Respondents were asked to identify the factors of service quality and quality of experience for the international tourists and national stakeholders. These factors of service and experience quality are important factors in measuring customer / tourist satisfaction.

\section{1- Tourists}

Tourist respondents considered that all the eleven factors of service quality and quality of experience were critical success factors. These critical factors of service quality and quality of experience success are : Improving product quality has the highest mean score and ranks 1 of the critical success factors of service quality and quality of experience. Therefore, tourist respondents considered it the most critical success factor as a key competitor in the

tourism market.

American tourists considered that improving product quality, divided the tourist site into factions and simplifying procedures are important factors to be competitive in the tourism market. However, West European listed management and competence of quality as having the ability to attract visitors

to the country. East European (including Balcan tourists) tourists totally agreed that service quality of tourism in Macedonia and Albania are consistent and dependable and can be guaranteed in advancing in the Macedonian and Albanian tourism market 
are important. Also, other tourists considered that range and speed of services impact on tourist's satisfactions encourages the tourists to come and repeat their visit to Macedonia and Albania. The following stakeholder factors have the same mean score and rank.

3- Service quality of tourism in Macedonia and Albania is consistent and dependable.

3- Simplifying procedures are to be competitive in increasing the availability of the tourist services in the tourism market.

5- Improving (product quality) is to be competitive in increasing the availability of the to urist services in the tourism market.

5- The quality of the Macedonian and Albanian tourism service can be guaranteed

8- Range of services influence on tourist's satisfactions.

8- Capability of quality in Macedonia and Albania tourism has the ability to attract visitors to the country.

However, these stakeholder factors were listed by the respondents in the same order of importance as improving Macedonia and Albania's tourism products. This meant that these stakeholder factors have the ability and competitive advantage in attracting visitors to Macedonia and Albania and increasing the availability of the tourist services in the touris m market.

Managers of restaurant, accommodation and travel agents and tour operators agreed that service and management quality of the Macedonian and Albanian tourism have good relationship with tourism stakeholders. However, they are key influences on the speed of information interchange between the supplier and the tourist that have an impact on tourists' attractions.

Managers of tourism as sociations and transport listed service quality of tourism in Macedonia and Albania and

simplifying procedures are consistent and dependable. Thus, these are the challenger factors in increasing the availability of the tourist services in the tourism market.

Sales and marketing managers totally agreed with the quality of the Macedonia and Albanian tourism service and improving product quality can be guaranteed are to be competitive in the tourism market. However mangers of hotels and provincial tourism considered that speed of service and divided the tourist site into factions increased tourists' satisfaction to come and repeat their visit to Macedonia and Albania.

Employees of tourism associations and local publicity considered that the range of services and quality competence of the Macedonian and Albanian tourism are the most critical factors that have the ability to attract visitors to the country.

\section{3- Comparis on of Service Quality between Tourists and Stakeholders}

The are the differences of service and experience factors between tourists and stakeholders in Macedonia and Albania. Tourist respondents agreed that all the eleven elements of experience and service quality for tourists are important factors by a percentage ranging from $90.2 \%$ to $40.5 \%$, while experience and service quality for stakeholders are important factors by a percentage ranging from $80.4 \%$ to $5.3 \%$.

Tourist respondents considered that improving service quality of tourism product is a key tool in increasing the availability of the tourist services in the tourism market, while stakeholder respondents considered that simplifying procedures are to be competitive in increasing the availability of the tourist services in the tourism market.

In addition, tourist respondents considered that speed of service increases tourists' satisfaction to come and repeat their visit to Macedonia and Albania, while stakeholders considered that service quality of tourism is a key influence on the speed of information interchange between the supplier and the tourists.

Tourist respondents considered that the factor of capability in quality of Macedonia's and Albania's tourism has the ability to attract visitors to the country is important. Therefore, this is an important success factor in advertising and encouraging Macedonian and Albanian tourism as a destination area with $66.2 \%$, while stakeholders considered it so with $8.6 \%$.

From the stakeholders' point of view, respondents ranked the following factors of service quality for stakeholders in order of importance and the same factors for tourists in a different order of importance.

1- Service quality of tourism is a key influence on the speed of information interchange between the supplier and the tourists with $80.4 \%$, but for tourists it came number 8 with $45.8 \%$.

2- Management of quality has a relation with tourism that can be treated as a service with $62.6 \%$, while for tourists it came number 11 with $41.5 \%$.

The stakeholders considered service quality of tourism as a key influence with a ranking of 1 , followed by the management of quality. This is true in the marketing context, but tourist respondents considered them less important factors since their rankings were 8 and 11 , respectively.

However, in a marketing context, respondents and marketers considered management of service quality has a strong impact upon increasing tourist's satisfaction to come and repeat their visit to the destination, which in this case is Macedonia and Alb ania.

Respondents for tourists gave management of service quality a mean score of 3.9 and ranking of 11 as critical factor and, for stakeholders, 4.65 and rank 2. Therefore, decision-makers always need management quality to have influence on increasing tourist's satisfaction.

Tourist respondents considered that improving service quality of tourism product is a key tool in increasing the availability of the tourist services in the competitive tourism market, while stakeholder respondents considered simplifying procedures are to be competitive in increasing the availability of the tourist services in the tourism market. 
In addition, tourists considered speed of service increases customer's satisfaction and attracting visitors to Macedonia and Albania, while stakeholders considered service quality of tourism is a key influence on speeding the services to tourists as most important factors.

The tourist respondents considered the factor of capability in quality of Macedonia and Albania tourism has the ability to attract visitors to the country as an important success factor in selling and promoting Macedonian and Albanian tourism as a destination area with $66.2 \%$, while stakeholders considered it important with $8.6 \%$.

Tourists from East European are totally agree that service quality of tourism in Macedonia and Albania are consistent and dependable and can be guaranteed are important factors in advancing in the Macedonian and Albanian tourism market. Also, other tourists considered range and speed of services as important factors in improving the Macedonian and Albanian tourism market. Consequently, they disagree with American tourists who considered that improving product quality, divided the tourist site into factions and simplifying procedures are important factors to be aggressive in the tourism market.

Sales managers totally agreed with marketing managers that the quality of the Macedonia and Albanian tourism service and improving product quality can be guaranteed are important factors for aiming to be ready for action in the tourism market. Managers of hotels and provincial tourism considered that speed of service and divided the tourist site into factions increased tourists' satis faction to come and repeat their visit to Macedonia and Albania. Nevertheless, they disagree with travel agen ts and tour operators who listed service and management quality of the

Macedonian and Albanian tourism as critical factors of service and experience quality success in measuring the tourist satisfaction and pleasing to the eye of the tourism destinations.

\section{Destination Marketing Management of Pricing Strategy}

Destination marketing strategy of pricing has affected tourist satisfaction and achievement of its objectives. Tourist and stakeholder respondents considered that all factors of price are critical success factors.

\section{1- Tourists}

The following factors of price are the most critical success factors identified by respondents in order of importance.

1- Accomplishing lowest possible charge is competitive in attracting tourists to the tourism sites.

2- The value of Macedonian and Albanian air travel is dependent on the length of stay at the destination area.

2- Price setting can be marketing-oriented based upon its considerations.

4- Competition is one of the driving forces towards lower prices.

The critical factors of price for tourists identified by respondents that have the same mean score and rank are price setting and the value of Macedonian and Albanian air travel. Therefore, those two critical success factors can be marketing-oriented and the same importance of order in choosing the destination of stay.

From the tourists' perspective, Far Eastern tourists identified that accomplishing lowest possible charge is competitive in attracting tourists to the tourism sites. However,

Balcan tourists totally agreed that pricing of Macedonian and Albanian tourism dynamics examines the important issues affecting the reactions to competitors' price moves, while West European touris ts considered charges and fees have an impact on tourists' attractions.

Price factors were considered to be tools of weapon in the tourism market for the following reasons: firstly, they are challengers' success factors of pricing tourism products; secondly, they are motivators in mobilising the tourism market movements; finally, they are sudden impacts on tourist satisfaction for increasing numbers of visitors to the destinations In the context of tourism, East European tourists listed price is a value to the tourist customer and a factor in the competitive tourism market. Howeve r, others tourists identified that increasing visitors to Macedonia and Albania are to be competitive in the tourism market, while East European tourists totally agreed that the price of stay in Macedonia and Albania is competitive, and American tourists considered that competition is one of the driving forces towards lower prices.

The following factors were added by the respondents: work as one to sell Macedonia and Albania as a whole; budget for destination marketing research; obtain government assistance with funding; platforms and simplifying and reducing the cost of training. Nevertheless, these factors added value to be all critical success in selling Macedonia and Albania as a whole with government help that have budget for destination marketing research and training cost reduction.

\section{2-Stakeholders}

The results of the factors of price for stakeholders identified by respondents are:

The mean score of these critical success factors of price for stakeholders varied between 4.75 and 4.05.

From the stakeholders' perspective, these are the critical success factors of price, in order of importance.

1- The value of Macedonian and Albanian air travel is dependent on the length of stay at the destinations area.

2- Increasing numbers of visitors to Macedonia and Albania are to be competitive in the to urism market.

3- Competition is one of the driving forces towards lower prices.

4- Charges and fees have impact on tourist's attractions.

5- The price of stay in Macedonia and Albania is competitive.

6- Accomplishing lowest possible charge is competitive in attracting tourists to the tourism sites. 
6- Price is a value to the tourist customer and a factor in the competitive tourism market.

8- Price setting can be marketing-oriented based upon its considerations.

9- Pricing of Macedonian and Albanian tourism dynamics examines the important issues affecting the reactions to competitors' price moves.

Stakeholder respondents gave the same mean score and rank for the two critical success factors of price: accomplishing lowest possible charge and price is a value to the tourist customer. Consequently, those two critical success factors have a common factor that impacts on the competitive tourism market.

Managers of hotels and local publicity employees considered that the value of Macedonian and Albanian air travel is dependent on the length of stay at the destination area, while managers of tourism attractions and employees of tourism associations identified increasing numbers of visitors to Macedonia and Albania are to be competitive in the tourism market, but marketing and sales managers totally agreed with competition is one of the driving forces towards lower prices.

In the marketing context, managers of provincial tourism listed charges and fees have an impact on tourists' attractions, while transport managers considered that pricing of Macedonian and Albanian tourism dynamics examines the important issues affecting the reactions to competitors' price moves. Thus, travel agents and tour operators identified that price setting can be marketing oriented based upon its considerations and managers of restaurants and accommodation totally agreed that the price of stay in Macedonia and Albania is competitive.

\section{3- Comparison of Price between Tourists and Stakeholders}

Respondents identified the critical success factors of price for international tourists from $92 \%$ to $59 \%$, and national stakeholders from $84 \%$ to $22 \%$. Respondents considered the critical success factors of price for stakeholders in order of importance and the same critical success factors for international tourists in a different order of importance.

1- Rank 1 for stakeholders came 2 for tourists that the value of Macedonian and Albanian air travel is dependent on the length of stay at the destination area.

2- Rank 2 for stakeholders came 7 for tourists where increasing numbers of visitors to Macedonia and Albania are to be competitive in the tourism market.

3- Rank 3 for stakeholders came 4 for tourists that competition is one of the driving forces towards lower prices.

4- Rank 4 for stakeholders came 6 for tourists where charges and fees have an impact on tourist's attractions.

According to the stakeholders' opinion, respondents considered that the value of Macedonia and Albanian

air travel, increasing numbers of visitors to Macedonia and Albania, competition and charges and fees that play a vital role in attracting tourists and competing of Macedonian and Albanian tourism in the intercontinental tourism market are the most critical success factors of pricing strategy for stakeholders. Hence, the most critical success factors of pricing strategy considered by the respondents for touris ts are accomplishing lowest possible charge, the value of Macedonian and Albanian air travel, price setting and competition that is to be competitive in the tourism market.

Tourist respondents considered that pricing of Macedonian and Albanian tourism is one of the most critical factors of price by $68.8 \%$, but stakeholder respondents considered it by $22 \%$. Thus, this factor is the most critical success factor in growing the availability of the pricing strategy of Macedonian and Albanian touris $m$ in the tourism market and creating greater return visitation to the destination area.

Stakeholder respondents considered that the price of stay in Macedonia and Albania is competitive with $59.9 \%$ while tourists considered it with $39.7 \%$. Stakeholder respondents considered price is a value to the tourist customer and a factor in the competitive tourism market with $59 \%$ while, touris ts considered it with $32.6 \%$.

From the stakeholders' point of view, respondents listed the price of stay in Macedonia and Albania and price is a value to the tourist customer as the most common factors in the competitive tourism market. Consequently, in the touris ts' view, respondents considered accomplishing lowest possible charge and price setting can be marketing-oriented based upon their considerations to be competitive in attracting touris ts to the tourism sites by encouraging new tourists to visit the destination area.

From the tourists' view, East European tourists have identified accomplishing lowest possible charge and pricing of Macedonian and Albanian tourism as competitive factors in attracting tourists to the tourism sites. However, they totally disagreed with West European tourists who considered that charges and fees have an impact on tourists' attractions. American tourists totally agreed that competition and price are the driving forces towards lower prices, adding a value to the tourist customer and an important factor in the competitive touris m market. As a result, they totally disagreed with others and Balcan tourists that the low price of stay and increased numbers of visitors to Macedonia and Albania are competitive factors of price in the tourism market.

From the stakeholders' point of view, managers of hotels and local publicity employees totally agreed with marketing and sales managers who considered that the value of Macedonia and Albanian air travel is dependent on the length of stay at the destination area, while they totally disagreed with managers of tourism attractions and employees of tourism associations who identified that increasing numbers of visitors to Macedonia and Albania are competitive in the tourism market.

In the marketing context, managers of provincial tourism listed charges and fees have an impact on tourists' attractions, while they totally agreed with transport managers who considered that pricing of Macedonian and Albanian tourism dynamics examines the important issues affecting the reactions to competitors' price moves. Thus, they also disagreed with travel agents 
and tour operators and managers of restaurants and accommodation who identified that price setting and the price of stay in Macedonia and Albania can be competitive in the tourism market and marketing-oriented based upon its considerations.

\section{Conclusions and recommendations}

This paper discussed destination marketing where the definition of the destination was one of the most used in the field of tourism, marketing, planning and development, and general research. Destination also contains many tourismaspects that can be found in various dimensions and on various regional levels. Different factors may have an influence on destination choice, i.e. cost, income, age, personality, distance, risk and motivation. Destination features and preference sets can be matched to specific psychographic profiles of tourists.

The destination concept stated the tourists' needs and wants in the industrial field. Therefore, the importance of the destin ation concept was determined by tourists' demands through the marketing services in terms of the concept of tourism as applied to tourists. There has been, in general, an increase in the applicability and principles of services destination marketing which has paralleled with the marketing services community.

Destination development has some important elements to attract outside interests to the destinations. These elements depend upon the location and complexity of the destination, while branding is part of destination developmen $t$ and is a powerful weapon in marketing that is tackled by increasing rivalry, product parity and substitutability. Therefore, the study of destination marketing development indicates that its organizations need to identify specific destinations to improve their marketing efforts.

The importance of the aspects is to apply a good relationship between the marketing of services and the marketing of destinations. These aspects, such as evolution, keys of database, influence factors, overall guidelines, information technology systems and DMOs of destination marketing, have been applied in this research. Destination database development is considered key to effective marketing that focuses directly on the question of who will control the information flow and market access within the tourism industry. This has led to new marketing requirements for reaching individual customers and meeting their needs. An analysis of the modern literature on critical factors of destination marketing has been undertaken in order to: provide a perspective on the nature and extent of critical factors of destination marketing success; identify possible sources of critical factors of destination marketing success; determine the importance of the success factor and how it can be measured.

\section{REFERENCES}

Allan, G. (2003). A Critique of Using Grounded Theory as a Research Method, Electronic Journal of Business Research Methods, Vol. 2. No. 1.

Althiyaman, A. \& Robertson, R.W.(1995b). Strategic Planning in Large Tourism Firms: An Empirical Analysis. Tourism Management. Vol. 16. No.3, pp. 199-205.

Archdale, G.(1991a). The Promotion of the Destination and the Tourist Products Through Information and the Role of the Public Offices for the Support of the Necessary Infrastructure, Proceedings of the International Conference on Computer Networking and the Public Tourist Organization, Assist-Perugia, Italy, 18-20 November, pp. 162-170.

Bosetti, V., Cassinelli, M., and Lanza, A. (2006). Benchmarketing in Tourism Destination, Keeping in Mind the Sustainable Paradigm. Natural Resources Management. Social Science Research.pp, 1-19.

Buhalis,D.(2000). Marketing the Competitive Destination of the Future. Tourism Management, Vol. 21, pp, 97-116.

Burke, J. and Lindblom, L.(1989). Strategies for Evaluating Direct Response Tourism Marketing, Journal of Travel Research, Vol.28, No.2, pp.33-37.

Chon, K.S.(1991). Tourism Destination Image Modification Process: Annuals of Tourism Research, Vol. 19. No. 2, pp, 360-363.

Chon, K.S (1992). Self-Image/ Destination Image Congru ity. Annuals of Tourism Research, Vol. 19, No. 2, pp, 360-363.

Cooper, C., Fletcher,J., Gilbert, D., and Wanhill,S. (1993). Tourism. Principles and Practice. London. pp.265-277.

Creswell, J.W. (1994). Research Design: Qualitative and Quantitative Approaches. Sage Publications: Thousand Oake, CA.4761.

Crouch, G.I. \& Ritchie, J.R.B. (1999). Tourism, Competitiveness and Societal Prosperity. Journal of Business Research, Vol. 44, pp, 137-152.

Control. 8th Ed, Prentice Hall, New Jersey USA. pp.294-307.

Kotler, P.(1999). Kotler on Marketing: How to Create, Win and Dominate Markets. New York, Press Free.

Lovelock, C. (1991). Service Marketing. 3rd Ed. Englewood Cliffs, Prentice.37-48.

Marr, N, E.(1987). Understanding Customer Service Increasing Competitiveness, International Marketing Review, Vol.4, No.3, pp.45-53.

McCullough, D. (1997). Quantitative vs. Qualitative Marketing Research.pp9-18.

McDonald, (2002), Marketing Plans: How to Prepare Them, How to Use Them, 5th Ed, Butterworth - Heinemann. 59-67.

Middleton, V.T.C. and Hawkins, R. (1998). Sustainable Tourism: A Marketing Perspective. Oxford: Butterworth Heinemann.

Morrison, A.(1998). Tourism: Bridges Across Continents (McGraw-Hill Australia). 13-21.

Ryan, C. (1995). Researching Tourist Satisfaction: Issues, Concepts, Problems. London, UK: Routledge. 20-31.

Seaton, A. (1997). Destination Marketing. In .A. Seaton, \& M. Bennett, Marketing tourism products: Concepts, Issues, Cases. London: Thomson Business Press. pp.76-93. 
Sheldon, P.J. (1993). Destination Information Systems. Annuals of Tourism Research, 20, 633-649.

Witt, S.F. and Moutinho, L. (1989). Tourism Marketing and Management Handbook, New York: Prentice Hall, Inc, 15-32.

Yoon,Y.(2002). Development of a Structural Model for Tourism Destination Competitiveness from a Stockholder's Perspective. Unpublished D Phil Dissertation. 